\title{
Quality as Antecedent of Customer Satisfaction
}

Submitted 11/03/21, $1^{\text {st }}$ revision 16/04//21, $2^{\text {nd }}$ revision 07/05/21, accepted 20/05/21

$$
\text { Joy Lynn R. Legaspi }{ }^{1}
$$

\begin{abstract}
:
Purpose: This paper provides a direction of the level of analysis - individual and products about the attributes that could directly affect quality characteristics.

Design/Methodology/Approach: Mapping of what has been researched and what empirical evidences have been reported.

Findings: Many of the tools used in managing quality today varies on the type of business and the way management and their employees accept the changes. Some successfully implemented while others did not.

Practical Implication: Generalizing quality has been difficult for managers to measure across the individual and products, there are certainly numerous researchers who constructively developed product and service- based quality characteristics.

Originality/Value: How complete and valid the explanation about quality attributes the literature provides.
\end{abstract}

Keywords: Attributes, customer satisfaction, extrinsic, intrinsic, product, quality, service.

JEL Codes: M40, M41.

Paper Type: Review article.

${ }^{1}$ Department of Accountancy, De La Salle University, Philippines.

Email: happylegaspi@gmail.com 


\section{Introduction}

Up to now managers are keeping on analyzing and capturing the best customer strategies to compete in a global economy. They are striving on how they will attract new customers; how they will offer higher quality products and services and think of more choices to satisfy customers' needs in line to establish customer repeat buying behavior ((David, 2008; Legaspi, 2020).

Anderson and Sullivan (1993) and Yi (1990) concluded that there was an empirical support for quality as an antecedent of customer satisfaction. The primary driving force of customer satisfaction were product's perceived performance and the customer's expectation. These can be measured through its customer-satisfaction index process.

Then, cost accounting and management accounting directly associate quality as one of the drivers of customer satisfaction, customer retention and loyalty. They believed that having a good internal business process such as reducing or eliminating defective and rework products, considering customer response time and on-time delivery of the product and service, can achieve higher customer satisfaction that can lead to lower quality cost and higher future revenue (Horngren et al., 2012; Atkinson et al., 2012).

In this review article, the researcher studied the direction of the level of analysis individual and products about the attributes that could directly affect quality characteristics.

\section{Mapping of What Has Been Researched and Empirical Evidence Has Been Reported}

\subsection{The Basis of Customer Satisfaction}

The appropriateness behind measuring customer satisfaction creates long standing issues between the economists, theorists, and psychologists' perception, if customer satisfaction is actually comparable across individual and product categories (Jorgerson, 1990; Yi, 1990; Westbrook and Oliver, 1981).

The economist's perspective denotes the term satisfaction as equivalent to "utility" (Samuelson and Nordhaus, 2011), a word used and developed by economists to be able to derive the relationship of supply and demand curve. It is a scientific concept that economists use to understand how an ordinary consumer choose products and services and make decisions that will give them the greatest satisfaction or utility. For example, if Product A has higher utility than Product B, then consumers mean that they prefer to buy or use product A over B. This ranking indicates how the purchasers take into account the subjective pleasure or usefulness that they derive from consuming products and services (Camerer et al., 2003). 
Then, theorists expressed that it is measurable and comparable across individuals and therefore, it is important to be part of the companies planning and strategy formation. This information corresponds to the earliest economists view point, that, by studying the relationship between supply and demand curve, they are capable to measure and study how an ordinary customer chooses products and services and make decisions that will give them the greatest satisfaction or utility.

The notion of utility was basically developed by Daniel Bernoulli (Samuelson and Nordhaus, 2011) and observed that people are averse to risk. They want to make sure that for every dollar they spend there will be a corresponding gain than a dollar they stand to lose. Then, Jeremy Bentham (1802) extended the utility concept through their studies and included that consumer behavior was also necessary for drawing up clearly the consumers' consumption decisions.

Through their valuable ideas, Fornell and Johnson (1991) developed a framework for comparing customer satisfaction and associated the main factors identified by economics and psychological researchers concerning the two key elements that could directly affect customer satisfaction, namely: product performances and product expectations. Their studies link the elements across the individual and product category. They emphasized exactly how the customer satisfaction can be measured directly or indirectly using the multiple indicators approach. Still, their studies proved that utility concept stand as one of the best approaches to measure satisfaction and all products and services are comparable using the weighted average satisfaction indicators.

However, Oliver (1993) argued that there was distinction between customer satisfaction and quality. Customers require experience with a product to determine how satisfied they are with it. Quality, on the other hand, can be perceived without actual consumption experience. Also, it has been long recognized that customer satisfaction is dependent on value (Juran, 1988), where value can be viewed as the benefit received relative to costs incurred (Holbrook, 1994).

Moreover, Anderson et al. (1994) discussed that customer satisfaction is also dependent on price, whereas quality of a product or service is not generally considered to be dependent on price. As well as, Zeithaml (1988) viewed quality as it pertains to customer's current perception of a product or service, whereas satisfaction is based on not only current experience but also all past experiences, as well as future or anticipated experiences.

\subsection{What Quality Means?}

Quality may mean different things to different people. Dr. W. Edward Deming expert in quality control, stated as "the pride of workmanship" (cited in Aguayo 1990) while Philip Crosby another famous quality expert, defined as "conformance to requirement" (Crosby, 1979). 
In managerial accounting perspective, Atkinson et al. (2012) explained two major factors that could directly affect quality such as (1) the features and functionality or performance of the product in satisfying customer expectations and (2) the technical aspects of product design and performance specifications agreed with the manufacturers expected standards.

Likewise, in cost accounting viewpoint, Raiborn et al. (2006) generally defined quality as conformity to designated specification of a given product. Raiborn et al. (2006) classified customer expectations and manufacturer standards of Atkinson et al. (2012) into consumer and production view of quality. These can be measured through the ability of the products and services to meet and satisfy all the specific needs of consumers at a reasonable cost and by the capacity of good output generated from a specific amount of input used by the manufacturer (Legaspi, 2019).

However, Hauser and Shugan (1983) under marketing and economics standpoint, viewed quality and conceptualized based on the different levels of product attributes that come into agreement with Holbrook (1981) and strengthen that quality is same thing as the exact or the specific features of an object.

Then again, Olson and Jacoby (1972) believed that the attributes or features of Holbrook (1981) and Hauser and Shugan (1983) can be divided into intrinsic and extrinsic elements of quality. The intrinsic aspect relates to the physical composition of the products and services or the product itself while the extrinsic aspect belongs to the outside characteristics of the products (e.g., price, logo or symbol, design and the brand name). On the other hand, the American Society for Quality Control (1990) simplified and measured quality as the overall characteristics of a product or service that exactly meet and achieved the implied needs of the individual acquiring it.

\subsection{Importance of Quality}

From cost and management accounting point of view, it is important for every organization to manage the cost of their products in order to successfully enter and maintain their new and existing products on the market (Raiborn et al., 2006; Atkinson et al., 2012; Horngren et al., 2012). Reducing the variable and fixed production costs are the usual approach in cutting costs, for example, purchasing less expensive raw materials and paying laborers at a lower rate or laying off some of the lowest paid workers (Legaspi, 2019).

However, the proposition underlying the cost reduction this day is to decrease costs while upholding and developing product quality in order to be competitive. Through this, it is very important for the management to watch where they cut costs.

Garrison et al. (2011) discussed that defects cause costs. Mostly, if the defects and spoilage are inherent or normal part of the production process, companies included the cost as part of the manufacturing cost (Horngren et al. 2012) resulting to a higher 
cost of products. Poor service on the other hand, created disastrous company images. Are there any fast ways to improve customer satisfaction and reduce cost of fulfillment? How can the company anticipate and exceed the expectations of customers and markets without errors, on time, every day?

After World War II, Japanese led the application of system known as Lean Production in 1950. The model was pioneered by the Toyota Company. They discovered that in order to avoid large inventories, it is better to wait for the customer's order or demand. Then, process and complete the products at the end of the day and ship immediately to the customers. They believed that doing everything just in time will help them eliminate defects and deliver it on time (Atkinson et al., 2012). Although it creates difficult cultural change for an organization, Virginia Mason Hospital, a service business, productively fit the implementation of Lean Production in the health care environment (Black, 2008). It helped the hospital to shorten their patients waiting time for a doctor or test result.

During 1980s and after Toyotas' effective production system, the quality issues has been the focal point for businesses worldwide. Companies invest to improve its product and service quality by applying the Total Quality Management (Simmerman, 1992; Raiborn et al., 2006; Garrison et al., 2011; Atkinson et al., 2012; Horngren et al., 2012). The program consists of three objectives: (1) achieving and sustaining the quality of the products and services produced and rendered to persistently meet the customer's implied or stated needs, (2) the management must be confident that they sustained the quality level they achieve and (3) the management should develop the customer confidence to believe that the product they purchased or received is the intended quality they expect (Borthick and Roth 1992).

In relation to the objectives, Total Quality Management consist of four elements and arranged according to sequence: prevention cost, appraisal cost, internal cost, and external cost. Preventing product defects at the earlier stage of manufacturing process and in rendering services such as employee training, advance development of systems and technical support provided to suppliers are some solutions to limit the appraisal cost that represents the mistakes not eliminated through prevention activities. If the company avoid this cost, then it will cause reduction of the internal and external costs (Simmerman, 1992; Raiborn et al., 2006; Garrison et al., 2011; Atkinson et al., 2012; Horngren et al., 2012; Legaspi, 2014). These mean that if the quality of goods and services does not meet to quality standards, then the companies will suffer to a cost known as nonconformance.

In spite of this, an empirical study made by American Quality Foundation and Ernst \& Young opposed that Total Quality Management actually did not produced the desired effects for the companies. Based on the survey completed, the companies specifically indicated the undesirable effect on their economic returns and competitiveness. But instead, the companies complained that they were just wasting 
their time and effort in trying to improve the quality of their products (American Quality Foundation, 1992). Ford Motor Company, as an example faced big problems with its supplier, the Bridgestone/Firestone North America. Ford suffer billions of dollars for the defective tires delivered for their Ford Explorers and Ford Excursion SUVs that cause a lot of accidents and deaths. In total, the quality problem costs were high, that made Ford brought down their profits during the year 2000 (Healey and Woodyard, 2000; White and Lundegaard, 2001; Hakim, 2004).

Then, after several years of global competition, the International Organization for Standardization (ISO) developed the ISO 9000 in 1987. The company can only have this certification if they can provide the highest quality production of their products and services. By following long procedures and process to ensure their customers that management has committed to implement quality improvement program. These international quality standards have been updated several times and it is now called ISO 9001-2008 (Clifford, 2005).

The standard created a big impact especially in European companies. For example, European buyers will buy only to those ISO 9000 certified suppliers. Through this case, the companies' option is to engage and be accredit in order for them to compete in the European market. Same with the United States Companies that engage in different trade in Europe were force them to comply with the ISO standards. Through the years the standards become the measurement of quality in international trade (Clifford, 2005).

Afterwards, in 1990s, another business process improvement has been successfully operated and introduced by Motorola and General Electric Company named Six Sigma system. The system helped the company by gathering feedback and factbased data on customers (Brewer and Bagranoff, 2004; Garrison et al., 2011). Trainers in the Six Sigma system used new computing technology to achieve quality criterion of six standard deviations, or 3.4 defects per million items produced. The system starts by way of defining the company goals, then measuring the scope of the data, followed by analyzing and identifying the root causes of the problems, ensuing the implementation of solutions to the problems and thriving that problems were fixed as planned and looking for business process improvement through the application of the new methods over time (Brewer and Bagranoff, 2004).

\subsection{The Attributes Used to Evaluate Quality}

Though overall comparison of customer satisfaction and generalizing quality has been difficult for managers to measure across the individual and products, there are certain numerous researchers who constructively developed product and servicebased quality characteristics. Garvin (1984) for example, provides eight dimensions of the customers quality expectations for the companies that offer services or create tangible products and divided into objective and subjective characteristics such as 
(1) Performance (2) Features (3) Reliability (4) Conformance (5) Durability (6) Serviceability and Responsiveness (7) Aesthetics and (8) Perceived Value.

Garvin (1984) explained that performance relates on how does a service or product works or functions effectively in relation to its multiple characteristics, for example, the ease of use and speed of products. Features on the other hand, pertains to the different elements or characteristics that a service or product contain. For instance, the fixtures, decorations, accessories needed to customize a product while reliability denotes that a service or product will carry out the exact performance on time as expected without failure or breakdown.

Then, Garvin (1984) said that conformance refers to which a product or service meet or fulfill the required standard such in the case of a company where all final product undergoes quality control check and pass the standard. For service, it requires a customer exit survey to test if employees' performance is inconformity with the company's standards. Next, durability enables the product to have an expected enduring, stable or long-lasting life before it deteriorates and need for replacement.

Also, Garvin (1984) mentioned that serviceability and responsiveness directly reflect the manner on how an employee do their job. It requires courteous and competent staffs to complete their work and assist their customers out of their convenience, ease, quickness and absolute service. At the same time aesthetics refers to creativeness to make an appealing environment, discern and catch the sight and heart of customers.

Lastly, Garvin (1984) included perceived value which is formed base on customers' opinion such as the perception of consumers in advertisement and reputation of product or service seen and heard in televisions, radios, company websites, catalogs, new papers, billboards and word of mouth advert. The first to six elements belongs to objective characteristics that companies can control while the seven and eight elements were customers opinion or attitude based on product awareness and experience.

However, Maynes (1976) and Sproles (1986) opposed about the degree of measurement used in defining objective and subjective quality. They thought that objective quality characteristics cannot be measured given that it does not exist and all quality characteristics can only describe as subjective since all evaluation were based on customers perception.

In spite of this, objective quality can be measured using the actual specifications rather than perceptual. For example, the General Electric customers asked about how they determined the quality of a product. Consumers pointed out based on the different components such as appearance, cleanliness and durability were considered as critical elements of a product and called as a user-based approach. 
Also, Olson and Jacoby (1972) argued with Maynes (1976) and Sproles (1986) opinions. They drew up a clear distinction and explained that quality can be measured using intrinsic and extrinsic attributes that users can understand. From the published quality ratings for example, Consumer Reports were used to evaluate and construct the standards to measure quality objectively. The intrinsic aspect relates to the physical composition of the products and services or the product itself while the extrinsic aspect belongs to the outside characteristics of the products (e.g., price, logo or symbol, design and the brand name).

Based on the empirical studies, researchers identified that price considered as the best measure of product quality (Court, 1939; Griliches, 1971). For instance, in the automotive industries, the investigation made from General Motors consumers revealed that customers preferred price as the best indicator of product quality. According to Court (1939) and Griliches (1971) price is best when there are no other elements or when it is the only available attributes. When price is associated with other attributes (intrinsic and extrinsic), price becomes less assuring while the exploratory studies made by Mazursky et al. (1985), the respondents selected the brand name among other information in expressing about the quality of merchandise and service.

To make the evaluation well-defined, Lutz (1986) extended the line of reasoning into search attributes and experience attributes. Whether the quality assessment pertains to goods or services, the important point to consider was the evaluation made before purchase or during consumption. The greater the portion of the assessment made the higher the consumers' effective judgment. For example, Lutz (1986) classified products into service, durable goods, nondurable goods and industrial products. Assessment before purchase or search attributes most likely applicable for durable goods and industrial products while during consumption or experience attributes appropriate for service and nondurable goods.

On the other hand, Maynes (1976) modelled different ideas that consumer judgment can be made only between comparisons of the same products with different brand name. Quality usually takes place when consumers are given the set of products with different brands. Through this, customers can evaluate the excellence or superiority of one product over another.

However, Bonner and Nelson (1985) on their empirical studies revealed that Lutz (1986) evaluations and Olson and Jacoby (1972) conclusions were somehow appropriate. The researchers test the consumers' preferences in terms of orange juice (drinking a beverage) flavor, fresh taste, good aroma and appetizing appearance. Bonner and Nelson (1985) concluded that drinkers of orange juice depend more on intrinsic rather than extrinsic attributes at the point of consumption.

Conversely, when consumers exercise the point of purchase (buying a beverage), the researchers discovered that packaging forms present as the best measure to evaluate 
and sensed the color, sugar, calories, vitamins content and etc. This assessment denotes that in absence of intrinsic elements buyers usually depend on extrinsic factors as the important quality indicators.

\section{Conclusions}

By way of evaluating their individual studies and definition, theorist, economists, psychologists, and academic researchers explained that customers' satisfaction can be measured. They linked the word satisfaction into the individual experiences and assessments based on the usefulness of the product that a customer purchased.

At the same time, product usefulness was connected by cost and management accounting authors through the word, quality. It is how the company can satisfy customers. Considering that, in order for the product to be useful, companies need to manufacture quality products and provide quality services. They gave importance as to the role of quality to attain customer satisfaction.

Throughout the discoveries and definitions described by the famous quality researchers and authors, the primary important point to consider by the company is to have the ability to understand the needs and wants of consumers given that defining what quality is all about will depends on the consumers' judgment and not the firm's assessment.

Convincingly, all researchers provided constructive and useful information for users to understand the different perspectives in measuring the objective quality attributes (performance, features, reliability, conformance, durability, serviceability and responsiveness) and subjective quality attributes (aesthetics and perceived value) of products. It is important to consider the type of products whether durable and nondurable goods and service. Products can be at point of initial purchase or repeat purchase, actual consumption (experience attributes) or actual purchase (search attributes). Also, by providing the customers a set of products they can simply determine the intrinsic and extrinsic factors of a given product.

By identifying the most important intrinsic, extrinsic, objective and subjective product and service quality attributes developed by previous researchers can help the firms to obtain direct and clear understanding of the right quality characteristics considered necessary components of their products and services. The managers can now decide whether to invest resources in improving their products and services or to put their money in promoting or advertising their products and services in order to improve perceptions of quality.

\section{References:}

Aguayo, R. 1990. Dr. Deming, New York: Simon and Schuster, p. xi. 
American Society for Quality Control. 1990. Finance, Accounting and Quality. Milwaukee, WI: ASQC, p. 3.

Anderson, E., Sullivan M. 1993. The Antecedents and Consequences of Customer Satisfaction. Journal of Marketing Science, 12, 125-143.

Anderson, E., Fornell, C., Lehmann, D. 1994. Customer Satisfaction, Market Share, and Profitability: Findings from Sweden. Journal of Marketing, 58, 53-66.

Atkinson, A., Kaplan, R., Matsumara, E., Young, M. 2012. Management Accounting: Information for Decision-Making and Strategy Execution, 6th ed. Pearson Education Ltd., England.

Betham, J. 1802. In: E. Dumont, Theory and legislation. London: Trubner, 1871.

Borthick, F., Roth, H. 1992. Will Europeans Buy Your Company's Products? Management Accounting, 28-29.

Bonner, G., Nelson, R. 1985. Product Attributes and Perceived Quality: Food, in Perceived Quality. Lexington, MA: Lexington Books, 64-79.

Brewer, P., Bagranoff, N. 2004. Near Zero-Defect Accounting with Six Sigma. Journal of Corporate Accounting and Finance, 67-72.

Camerer, C., Loewenstein, G., Rabins M. 2003. Advances in Behavioral Economics. Princeton University Press, Princeton, New Jersey.

Clifford, S. 2005. So Many Standards to Follow, So Little Payoff. Inc. magazine, 25-27.

Court, A. 1939. Hedonic Price Indexes and Automotive Examples. In: The Dynamics of Automobile Demand. New York: General Motors Corporation, 99-117.

Crosby, P. 1979. Quality is Free. New York: New American Library, p. 15.

David, B. 2008. Management: an introduction, 4th ed. Edinburge Gate, Harlow, PrenticeHall.

Fornell, C., Johnson, M.D. 1991. A framework for comparing customer satisfaction across individuals and product categories. Journal of Economic Psychology, 12, 267-286.

Garrison, R., Noreen, E., Brewer, P. 2011. Managerial Accounting, $13^{\text {th }}$ ed. McGraw-Hill Education, Asia.

Garvin, D. 1984. What Does Product Quality Really Mean? Sloan Management Review, 2543.

Griliches, C. 1971. Introduction: Hedonic Price Indexes Revisited. In: Price Indexes and Quality Change. Cambridge, MA: Harvard University Press, 3-15.

Hakim, D. 2004. Another Recall Involving Ford, Firestone Tires and S.U.V.'s. The New York Times, February.

Hauser, J., Shugan S. 1983. Defensive Marketing Strategies. Marketing Science, 2, 319-60.

Healy, J., Woodyard, C. 2000. Tires Concerns Go Back 1 1⁄2 Years Before Recall. USA Today, September, p. 1B.

Holbrook, M. 1981. Integrating Compositional and Decompositional Analyses to Represent the Intervening Role of Perception in Evaluative Judgment. Journal of Marketing Research, 18, 13-28.

Horngren, C., Datar, S., Rajan, M. 2012. Cost Accounting: A Managerial Emphasis, $14^{\text {th }}$ Ed. Pearson Education Ltd., England.

Jorgenson, D. 1990. Aggregate consumer behaviour and the measurement of social welfare Econometrica, 58, 1007-1040.

Juran, J.M. 1988. Juran's Quality Control Handbook, $4^{\text {th }}$ ed. McGraw Hill, New York.

Legaspi, J.L. 2014. The Impact of Management Accounting Literature to Practice: A Study of Management Accounting Concepts in the Philippines Industries. International Journal of Academic Research in Accounting, Finance and Management Sciences, 4, 347-65. 
Legaspi, J.L.R. 2019. Practical implications of management accounting information: A Personal journey. International Journal of Economics and Business Administration, 7(4), 136-148. https://doi.org/10.35808/ijeba/336.

Legaspi, J.L.R. 2020. What business strategy does and what management accounting is pursuing: A logistic regression analysis. International Journal of Economics and Business Administration, 8(1), 124-133. https://doi.org/10.35808/ijeba/413.

Lutz, R. 1986. Quality is as Quality Does: An Attitudinal Perspective on Consumer Quality Judgments. Presentation to the Marketing Science Institute Trustees' Meeting, Cambridge, M.A.

Maynes, S. 1976. The Concept and Measurement of Product Quality. Household Production and Consumption, 40(5), 529-590.

Oliver, R. 1993. A Conceptual Model of Service Quality and Service Satisfaction. In: Advances in Service Marketing and Management, 65-86.

Olson, J., Jacoby, J. 1972. Cue Utilization in the Quality Perception Process. In: Proceedings of the Third Annual Conference of the Association for Consumer Research. M. Venkatesan, ed. Iowa City: Association for Consumer Research, 167-179.

Raiborn, C., Kinney, M., Prather-Kinsey, J. 2006. Cost Accounting, $6^{\text {th }}$ ed. Thompson SouthWestern, Asia.

Samuelson, P., Nordhaus, W. 2011. Economics, $9^{\text {th }}$ ed. McGraw Hill/Irwin, Asia.

Simmerman, S.J. 1992. Improving Customer Loyalty. Business \& Economic Review, AprilJune, 4.

Sproles, G. 1986. The concept of Quality and the Efficiency of Markets: Issues and Comments. Journal of Marketing, June, 146-147.

Westbrook, R.A., Oliver, R.L. 1981. Developing better measures of consumer satisfaction: Some preliminary results. Association for Consumer Research, 94-99.

White, G., Lundegaard, K. 2001. Ford Admits Last Year's Quality Snafus Took Big Toll Over \$1 Billion in Profit. The Wall Street Journal, January, p. A3.

Yi, Y. 1990. A critical review of consumer satisfaction. Review of Marketing, American Marketing Association, 235-347.

Zeithaml, V. 1988. Consumer Perceptions of Price, Quality, and Value: A Means-End Model and Synthesis of Evidence. Journal of Marketing, 52, 2-22. 